\title{
Passing the test
}

\author{
What role should the federal government have in pre-college science education? David Goldston looks at \\ why the US Congress is acting now to help define that.
}

( ) n 9 August, President George W. Bush rather grudgingly signed into law the America Creating Opportunities to Meaningfully Promote Excellence in Technology, Education and Science Act. The scientific community has tended to focus on provisions that authorize doubling the budgets for the National Science Foundation (NSF), the Department of Energy's (DoE's) science programmes and the National Institute of Standards and Technology. But most of the statute's 148 pages are devoted to creating new and expanded programmes in pre-college science and mathematics education.

The focus on education should be welcomed and cannot be taken for granted. Congressional enthusiasm for pre-college science education has waxed and waned over the years (see Nature 446, 714; 2007). A high point was the National Defense Education Act, passed in 1958 in the wake of the Soviet Sputnik satellite mission, which inaugurated federal funding for the topic.

But in the early years of the Reagan administration, Congress eliminated the NSF's precollege education programmes in an effort to stem controversy over curricula and to rein in federal spending. That decision was reversed within a couple of years, but the programmes took some time to recover. About a decade later, Congress instructed the DoE to close down its pre-college education programmes, saying that they detracted from the agency's primary missions. In 2001, science education seemed to be an after-thought when Congress passed the No Child Left Behind Act, which requires testing pupils to evaluate the quality of schools. And as recently as 2005, Congress set up an inter-agency panel with an eye to pruning federal programmes in the area, implying that there were too many and that they were inadequately coordinated and evaluated.

So why has Congress now focused on science education? The most immediate cause of the turnaround was the Democratic takeover of Congress this year. Although plenty of Republicans in previous Congresses supported a revived federal role in pre-college science, the House Republican leadership blocked consideration of a competitiveness bill because vocal congressional conservatives and the White House opposed spending more and creating new programmes. (The main power of party leadership

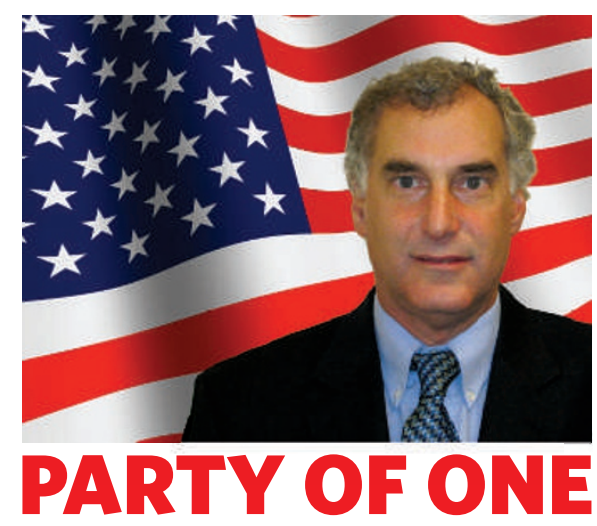

is its authority to schedule what comes before Congress for a vote.) But the longer-term change was aided by the willingness of business groups such as the Business Roundtable, which comprises the chief executives of around 160 major companies, to put some of their clout behind lobbying for improving pre-college education.

Now the question is whether enough has changed to make a difference. A law designed to bolster the NSF's role in education was enacted in 2002, but funding for the programmes didn't follow. The good news this time is that Congress seems to be willing to put its money where its mouth is. Next year's spending bills, for example, would provide the NSF's education programmes with their first real increase in four years - according to the American Association for the Advancement of Science. The Senate has the higher figure $-\$ 850$ million for the fiscal year that starts 1 October. And the programmes would increase at a faster rate than the agency as a whole. (The president is threatening to veto most of the upcoming spending bills, claiming that they are too large, so it's much too early to guess what will actually be signed into law.)

But not all of the new Congress's attitudes towards science and maths education are entirely beneficial. For example, Congress might have gone too far in focusing almost exclusively on equity issues in education. There's no question that the United States needs to target some of its education efforts towards schools in poorer school districts and under-represented minorities, especially as those groups become a larger proportion of the population. Federal programmes have an obligation to compensate for funding disparities in the nation's locally based education system, and indeed that's what most of the Department of Education's programmes are designed to do.

But the new law targets almost all of its numerous programmes towards schools in poor areas. That seems to go too far. Better teaching and other ways to interest more students in science are needed in a wide range of schools. The federal government needs a portfolio of programmes that engage with the full range of school districts - an approach that could be hampered by the new statute.

The new law does take a portfolio approach in one sense - it creates a dizzying array of sometimes overlapping programmes rather than setting priorities. That's because the only way to get the law passed so quickly — seven months after the start of the session - was to include almost every programme sought by interested legislators.

For example, the law authorizes at least four new pre-college programmes involving the national laboratories - pushed by Republican Senator Pete Domenici and Democratic Senator Jeff Bingaman, who, unsurprisingly given their home turf of New Mexico, are advocates for the labs. Encouraging the labs to interact more with schools makes good sense. But is it a good use of DoE funds to help states establish or expand schools that specialize in maths and science education that would then work with the labs? Probably not.

Interestingly, the DoE spending bills do not seem to set aside any money for education programmes, although they could still be funded out of general appropriations for DoE science, which are slated to rise next year.

As a whole, though, the new act is a plus for science education, especially given how uneasy Congress still feels about federal involvement in education 50 years after Sputnik. Back then, the National Defense Education Act opened with a statement that it was not intended to signal a federal takeover of education. And the new law explicitly states that the Department of Education "shall not endorse, approve or sanction any mathematics curriculum designed for use in any school" - even as it authorizes the department to fund projects designed to improve maths instruction in the neediest schools by using new instructional materials.

David Goldston is a visiting lecturer at

Princeton University's Woodrow Wilson School of Public and International Affairs. 